\title{
Ascending Frontal Artery
}

National Cancer Institute

\section{Source}

National Cancer Institute. Ascending Frontal Artery. NCI Thesaurus. Code C32152.

A cortical branch of the middle cerebral artery supplying the ascending frontal convolution. 